\title{
PEMBELAJARAN HURUF HIJAIYYAH PADA SENTRA AGAMA DI TAMAN KANAK-KANAK TUNAS 1001 TAKENGON ACEH TENGAH
}

\author{
Dewi Purnama Sari \\ UIN Sunan Kalijaga Yogyakarta \\ Email: dewipurnamapgra@gmail.com \\ Orcid ld: https://orcid.org/0000-0003-4889-9273 \\ Ardian Al Hidaya \\ STAI Madiun Jawa Timur \\ Email: ardwall99@gmail.com \\ Orcid ld: https://orcid.org/0000-0003-4487-7931 \\ Eliyyil Akbar \\ STAIN Gajah Putih Takengon Aceh Tengah \\ Email: elayakbar@gmail.com
}

Orcid ld: https://orcid.org/0000-0001-7135-9035

Article received: 22 Februari 2019, Review process: 27 February 2019

Article published: 30 September 2019

\begin{abstract}
The ability to read the verses of the Qur'an is decreasing, the motivation to read the Qu'ran is increasingly fading. Of course the next generation cannot be allowed to go on in conditions that are not conducive so that the basic learning of reading the Qur'an, namely knowing the letter by letter of the Hijaiyah letter becomes an important agenda to do since the child is still early. As what was done by Takengon 1001 Kindergarten is to teach hijaiyah letters by internalizing the religious center. This can be used as a reference for other educational institutions to provide a basis for the ability to read the Qur'an. The method used in this study is a research field with a qualitative approach. This paper examines the concept of hijaiyah letter learning at the religious center and the implementation of hijaiyah letter learning at religious centers in Takengon 1001 Kindergarten. Findings in the field that the concept of hijaiyah letter learning is interpreted as learning related to the verses of the Qur'an so that it can provide knowledge that someday children are able to read well and correctly. The learning process of hijaiyah letters with religious centers is done by planning to assessment so that aspects of children's language, motoric, cognitive, and social development can be achieved.
\end{abstract}

Keywords: Learning, Letter Hijaiyah, Center of Religion

\section{Abstrak}

Kemampuan membaca ayat-ayat suci Al-Qur'an semakin menurun, motivasi membaca al-Quran semakin memudar. Tentu generasi penerus tidak dapat dibiarkan berlarut dalam kondisi yang tidak 
kondusif sehingga pembelajaran dasar membaca Al-Qur'an yakni mengetahui huruf demi huruf dari huruf hijaiyah menjadi agenda penting untuk dilakukan sejak anak masih dini. Sebagaimana yang dilakukan oleh Taman Kanak-Kanak 1001 Takengon yaitu membelajarkan huruf hijaiyah dengan internalisasi pada sentra agama. Hal tersebut dapat dijadikan acuan bagi lembaga pendidikan lainnya untuk memberikan dasar kemampuan membaca Al-Qur'an. Metode yang digunakan dalam penelitian ini adalah field riset dengan pendekatan kualitatif. Tulisan ini mengkaji konsep pembelajaran huruf hijaiyah pada sentra agama dan pelaksanaan pembelajaran huruf hijaiyah pada sentra agama di Taman Kanak-Kanak 1001 Takengon. Temuan di lapangan bahwa konsep pembelajaran huruf hijaiyah dimaknai sebagai pembelajaran yang berkaitan dengan bagian ayat-ayat al-Qur'an sehingga dapat memberikan pengetahuan bahwa kelak anak mampu membaca dengan baik dan benar. Proses pembelajaran huruf hijaiyah dengan sentra agama dilakukan dengan perencanaan hingga penilaian sehingga aspek perkembangan bahasa, motorik, kognitif, sosial anak dapat tercapai.

Kata Kunci: Pembelajaran, Huruf Hijaiyah, Sentra Agama

\section{PENDAHULUAN}

Pendidikan anak usia dini (PAUD) pada hakikatnya diselenggarakan dengan tujuan untuk memfasilitasi pertumbuhan dan perkembangan anak secara menyeluruh atau menekankan pada pengembangan seluruh aspek perkembangan kepribadian anak. Oleh karena itu, pendidikan sejak dini memberikan kesempatan kepada anak-anak untuk mengembangkan kemampuan dan potensi secara maksimal. Konsekuensinya, lembaga PAUD perlu menyediakan berbagai kegiatan yang dapat mengembangkan berbagai aspek perkembangan seperti kongnitif, bahasa, sosial, emosi, fisik, motorik, agama serta moral (Suyadi, 2013: 17). Pendidikan yang diberikan pada anak usia dini merupakan sesuatu hal yang sangat penting dalam rangka mempersiapkan dan menggali potensi sejak dini melalui pembelajaran.

Pembelajaran pada anak usia dini dapat dilakukan dengan mengembangkan kurikulum secara konkret berupa seperangkat rancangan pembelajaran yang berisi pengalaman belajar melalui bermain dan diberikan kepada anak usia dini berdasarkan kemampuan dan perkembangan anak dalam rangka pencapaian kompetensi secara maksimal (Mursid, 2015: 34). Masa usia dini merupakan masa yang sangat menentukan setiap pertumbuhan dan perkembangan anak karena masa ini sangat kritis dan penting dalam kehidupan anak. Pembelajaran pada lembaga pendidikan meliputi pembelajaran umum dan agama. Pembelajaran agama dapat diberikan dengan mendukung aspek perkembangan moral anak. Pembelajaran agama sebaiknya diberikan sejak diri karena untuk membentuk pondasi dalam diri anak. Salah satunya dengan cara mengenalkan bacaan-bacaan kitab suci al-Quran yang 
dimulai dengan membelajarkan huruf hijaiyah. Huruf hijaiyah merupakan salah satu dari kunci ilmu pengetahuan, terlebih lagi yang berkaitan dengan ilmu-ilmu keislaman. Seorang anak yang telah menguasai huruf hijaiyah dengan baik, terbuka peluang untuk menggali khasanah dan mendalami ajaran-ajarannya. Kenyataan yang ada, sebagaimana yang dijelaskan oleh Supriadi dan Rahmat yang dikutip oleh Imroatun bahwa jumlah siswa SD-SLTP yang pintar membaca Al-Qur'an hanya sekitar 10\%, dengan munculnya metode Iqra ini jumlah siswa yang pintar membaca Al-Qur'an dapat naik menjadi sekitar 30\%. Hingga awal tahun 2000-an, jumlah siswa SD-SLTP yang pintar membaca Al-Qur'an masih bertahan, sekitar $30 \%$. Yang pintar membaca Al-Qur'an itu adalah mereka yang pernah memasuki TKA dan TPA. Sementara itu, para siswa yang tidak pernah memasuki TKA dan TPA hingga tamat SMU, bahkan saat mahasiswa, tidak pernah bisa membaca Al-Qur'an. (Imroatun, 2017: 175). Kesulitan dalam memahami huruf hijaiyah karena terdapat perbedaaan yang signifikan terhadap bahasa Indonesia yang bersumber pada huruf latin sebagai bahasa nasional.

Oleh karena itu, membelajarkan huruf hijaiyah sejak dini menjadi agenda penting sehingga menciptakan generasi yang dapat membaca Al-Qur'an. Pengenalan huruf hijaiyah adalah kunci utama dasar untuk mampu membaca Al-Qur'an. Makna huruf, bagi seorang muslim, menjadi kebutuhan dasar dalam memahami kedua pedoman pokok kehidupannya. Hijaiyah atau juga sering dikenal sebagai huruf Arab itu berjumlah 29 huruf. Huruf itu kemudian merupakan bagian dari bahasa Arab yang menjadi bahasa pokok dalam Quran. Memang tidak sedikit lembaga sekolah yang sudah mengajarkan atau mengenalkan huruf hijaiyah namun banyak yang kurang dapat memahami karena kurang tepatnya metode atau penggunaan metode yang monoton. Pada pembelajaran di Taman Kanak-Kanak Tunas 1001 Takengon salah satu upaya yang dilakukan dalam pembelajaran huruf hijaiyah yaitu dengan metode sentra agama. Pada dasarnya pembelajaran pada sentra agama dapat meningkatkan dasar kemampuan membaca Al-Qur'an anak lebih maksimal.

Dalam kegiatan sentra, anak dirangsang untuk aktif dalam kegiatan belajar, anak menjadi pusat pembelajaran dan guru lebih berperan sebagai motivator dan fasilitator yang memberikan pijakan-pijakan kegiatan. Dalam pijakan-pijakan anak mendapatkan pengetahuan yang lebih dalam, kosa kata baru dan ide-ide yang dapat dituangkan ke dalam kegiatan bermain. Sentra agama termasuk salah satu sentra pada pendekatan belajar Beyond Center and 
Circle Time (BCCT) yang difokuskan agar setiap guru dapat menghadirkan dunia nyata dan mendorong anak dapat membuat hubungan antara pengetahuan, pengalaman, dan penerapan dalam kehidupan mereka sehari-hari. Sehingga otak anak dirangsang untuk terus berfikir secara aktif dalam menggali pengalamannya sendiri bukan sekedar mencontoh dan menghafal. Sebagaimana yang terjadi di Taman Kanak-Kanak Tunas 1001 Takengon, pembelajaran huruf hijaiyah dengan menggunakan sentra agama, anak-anak lebih mudah dan fokus kepada pembelajaran huruf hijaiyah dan masih sedikitnya sekolah menerapkan pembelajaran sentra agama dengan mengenalkan huruf hijaiyah. Tulisan ini mengulas tentang konsep pembelajaran huruf hijaiyah pada sentra agama Di TK Tunas 1001 dan pelaksanaan pembelajaran huruf hijaiyah melalui sentra agama Di TK Tunas 1001.

\section{Pembelajaran Huruf Hijaiyah}

Istilah pembelajaran dapat didefinisikan dari berbagai sudut pandang. Salah satu sudut yang dianggap paling awal menyajikan konsepsi pembelajaran adalah sudut pandang behavioristik. Berdasarkan pandangan teori ini, pembelajaran sering dikatakan sebagai proses pengubahan tingkah laku anak melalui pengoptimalan lingkungan sebagai sumber stimulasi belajar (Hamalik, 2013: 57). Keberhasilan pembelajaran dalam konsep ini sangat bergantung pada keberartian interaksi multi arah. Oleh sebab itu, interaksi yang dimaksud dalam proses pembelajaran adalah interaksi edukatif, yakni interaksi yang berfungsi untuk mengembangkan berbagai potensi yang dimiliki anak dalam rangka membangun pengetahuan pada dirinya. Interaksi ini sebaiknya mampu membangun inspiratif, menyenangkan, menantang, memotivasi, serta memberikan ruang yang cukup bagi prakarsa, kreativitas, dan kemandirian sesuai dengan bakat, minat, dan perkembangan fisik serta psikologis anak (Yunus, 2014: 1-2). Pembelajaran untuk anak bukan hanya bermain namun juga membangun pengetahuan berupa huruf, angka, warna, bentuk. Fokus pembahasan ini adalah pembelajaran huruf.

Menurut Carol Seefelt dan Barbara A.Wasik, bahwa pemahaman mengenal huruf adalah kemampuan dalam melakukan sesuatu dengan mengenali tanda-tanda/ciri-ciri dari tanda aksara dalam tata tulis yang merupakan anggota abjad yang melambangkan bunyi bahasa (Carol, 2006: 330-331). Belajar huruf adalah komponen hakiki dari perkembangan baca tulis. Anak bisa membaca beberapa kata dan mengenal huruf cetak dilingkungan/ environmental print sebelum mereka mengetahui abjad. Anak menyebut huruf pada daftar 
abjad, dalam belajar membaca tidak memiliki kesulitan dari pada anak yang tidak mengenal huruf (Carol, 2006: 330-331). Burnett menyatakan bahwa mengenal huruf merupakan hal penting bagi anak usia dini yang didengar dari lingkungannya baik huruf latin, huruf Arab dan lainnya.

Berbagai huruf yang dikenal anak menumbuhkan kemampuan untuk memilih dan memilah berbagai jenis huruf. Melatih anak untuk mengenal huruf dan mengucapkannya mesti harus diulang-ulang (Harun, 2009: 241). Mengenal huruf untuk pendidikan anak usia dini, yaitu anak belajar mengenal huruf dan bunyinya dari konteksnya dari bahasa yang digunakan. Anak diarahkan untuk mengidentifikasi bentuk huruf dan bunyinya. Jadi anak belajar dari konsep menyeluruh menuju ke konsep khusus (Susanto, 2011: 86). Selain pendapat tersebut, mengenal huruf bukan hal yang mudah salah satu penyebabnya adalah karena banyak huruf yang bentuknya mirip tetapi bacaannya berbeda, seperti huruf " $D$ " dan huruf "B", huruf "M" dengan huruf "W", maka diperlukan permainan atau cara membaca untuk mengenal huruf (Slamet, 2005: 165).

Penerapan pembelajaran huruf dapat menunjang bahasa anak secara baik. Bahasa tumbuh sesuai dengan penggunanya di masyarakat yang memiliki ciri khas masing-masing. Kedekatan keduanya menyebabkan bahasa bisa diperoleh sejak lahir oleh seorang anak. Kemampuan anak berbahasa kemudian diperoleh melalui peniruan dari lingkungannya dan berkembang secara alami. Proses bahasa terjadi melalui alam bawah sadar, imitasi berproses dalam komunikasi langsung bersama para orang tua dan keluarga pengguna bahasa dominan yang ada dalam lingkungan sekitarnya, baik dalam keluarga maupun masyarakat yang diajak berinteraksi. Karena itu, perolehannya tersimpan secara jangka panjang dalam ingatan. Proses demikian dikenal dengan pemerolehan bahasa (iktisab al-lugah/language acquisition) yang berbeda dengan pembelajaran bahasa (ta'limiyyah al-lugah/ learning acquisition). Bahasa yang diperoleh kemudian cenderung menjadi bahasa pertama atau bahasa ibu. Macam-macam huruf terdapat huruf abjad dalam konteks bahasa indonesia dan huruf hijaiyah dalam konteks bahasa arab.

Huruf hijaiyah memiliki arti huruf seperti yang kita kenal dalam bahasa Indonesia yang terdiri dari 26 huruf. Sedangkan dalam bahasa Arab terdapat 28 huruf yang kita kenal dengan huruf hijaiyah. Berdasarkan uraian terebut di atas, dapat disimpulkan bahwa 
kemampuan mengenal huruf hijaiyah adalah penguasaan mengenali huruf-huruf dan bunyi dari huruf hijaiyah yang berjumlah 28 huruf berdasarkan bentuk, bunyi dan konteksnya dari bahasa yang digunakan, dalam hal ini bahasa al-Qur'an. Huruf hijaiyah disusun atas dua bentuk yaitu mufrad (tunggal) dan muzdawij (berangkai) yang ditulis dan dibaca dari kanan ke kiri. Bentuk huruf hijaiyah berbeda-beda. Beberapa huruf hijaiyah berbentuk sama yang membedakan adalah titiknya. Huruf hijaiyah bertitik satu, dua, atau tiga. Tempat titik juga bisa berbeda, ada yang di atas, di dalam, dan di bawah. Oleh karena itu yang dimaksud dengan huruf hijaiyah adalah huruf-huruf ejaan dalam bahasa Arab yang merupakan sebagai bahasa asli Al-Qur'an.

Beberapa ungkapan bahkan ada yang secara eksplisit mengakui bahasa Arab sebagai ungkapan-ungkapan lisan dari sebagian dari huruf hijaiyyah. Huruf hijaiyah merupakan alfabeta Arab yang disebut dengan huruf al hija (iyah) dan huruf al tahajji artinya huruf ejaan. huruf al 'Arabiyah itu terdiri dari huruf yang bertanda baca atau bertitik (huruf al-mu'jam), baik dalam bentuk terpisah-pisah yang belum dipahami kecuali setelah menjadi sebuah rangkaian kata ataupun sebagian atau seluruhnya telah ditambahi dengan tanda baca. Dengan kata lain, hijaiyah adalah pokok utama dalam mengenal huruf yang digunakan dalam bahasa Arab untuk membaca Al-Qur'an. Huruf hijaiyah merupakan sebuah penyusunan kata dalam al-qur'an. Seperti halnya di indonesia yang memiliki huruf alphabet dalam menyusun sebuah kata menjadi kalimat, huruf hijaiyah juga memiliki peran yang sama yang menyusun sebuah kata dan menjadi sebuah kalimat (Arsyad, Azhar: 1999: 32).

Salah satu dasar yang penting untuk memperkenalkan huruf hijaiyyah adalah bagaimana seseorang dapat membedakan huruf dengan jelas .Inilah yang disebut dengan istilah makhraj huruf. Makhraj dari segi bahasa adalah tempat keluar, sedangkan dari segi istilah makhraj diartikan tempat keluarnya huruf. Pembelajaran huruf hijaiyah bisa diaplikasikan secara terencana, bertahap, berulang-ulang, konsisten, hingga evaluasi secara tuntas dengan intensitas waktu yang cukup. Pembelajaran hijaiyah bagi anak usia dini patut dipertimbangkan secara masak-masak oleh pendidik karena dapat mempermudah dalam memahami Al-Quran sesuai dengan aspek perkembangan yang dimilikinya. Pembelajaran hijaiyyah di Taman Kanak-Kanak memerlukan komitmen bersama dan integrasi dari semua lingkungan pendidikan, dari sekolah, masyarakat dan keluarga. Hal itu memberikan dampak 
pada penciptaan lingkungan bahasa Arab yang permanen dan berkelanjutan bagi anak. Sehingga kesempatan yang luas dan intensitas yang tinggi dalam konteks sosial yang sesuai dan memberikan kenyamanan bagi anak, tanpa merasakan adanya kesenjangan. Hal itu juga ditekankan oleh Kementrian Pendidikan dan Kebudayaan RI (2013) ketika menjabarkan penyelenggaraan PAUD berbasis Quran. Tujuannya untuk mengoptimalkan perkembangan anak pada usia emasnya dan untuk memastikan bahwa anak belajar melalui bermain yang disesuaikan dengan tahap perkembangan dan potensi masing-masing anak tanpa paksaan. Pembelajaran huruf hijaiyah tentu memiliki metode atau cara berbeda-beda sesuai dengan ciri khas dari masing-masing metode yang dikembangkan sebagaimana pembelajaran pada sentra agama.

\section{Sentra Agama}

Sentra berasal dari kata "centre" yang artinya pusat. Seluruh materi yang dialirkan oleh guru kepada anak melalui kegiatan-kegiatan yang sudah direncanakan dan perlu diorganisasikan secara teratur, sitematis dan terarah, sehingga anak dapat membangun kemampuan menganalisisnya dan dapat mempunyai kemampuan mengambil kesimpulan. Sentra mengandung makna bahwa setiap kegiatan di semua sentra yang disediakan memiliki titik pusat (centre poin), yang semuanya mengacu pada tujuan pembelajaran. Sentra, yang dikenal lebih jauh dengan sebutan sentra dan saat lingkaran yang berasal dari beyond centers and circle time (BCCT), merupakan konsep pembelajaran anak usia dini yang resmi diadosi oleh Departemen Pendidikan Nasional Republik Indonesia sejak tahun 2004.

Penemuan dan pengembangan BCCT, yaitu Dr. Pamela Phelps yang merupakan tokoh pendidikan di Amerika Serikat yang telah mengabdi lebih dari 40 tahun di dunia pendidikan anak usia dini, melalui sekolah creative preschool di Tallahase Florida, sekaligus menjadi konsultan bekenaan dengan penerapan konsep pembelajaran tersebut di indonesia. Dengan penerapan konsep sentra dan waktu lingkaran di bangun dapat membentuk beberapa sikap antara lain iklas, sabar, mutu, rajin, berfikir positif, hormat, ramah, kasih sayang, rendah hati, membawa anak berakhlak mulia.

Pendekatan sentra dan lingkungan adalah pendekatan penyelenggaraan PAUD yang berfokus pada anak yang dalam proses pembelajaran berpusat di Sentra main dan saat anak 
dalam lingkaran dengan menggunakan 4 jenis pijakan (scaffolding) yaitu bantuan bersifat sementara untuk mendukung perkembangan anak didik melalui struktur bantuan untuk mencapai tahapan atau tingkat berikutnya. Selama kemampuan pembelajaran bertambah, maka scaffolding yang diberikan makin lama makin berkurang dan anak dapat menuntaskan tugas dengan sendirinya. Untuk mendukung perkembangan anak yaitu (1) pijakan lingkungan main; (2) pijakan sebelum main; (3) pijakan selama main; (4) dan pijakan setelah main (Depdiknas, 2006: 2). Sentra adalah pusat kegiatan belajar atau pusat sumber belajar yang merupakan suatu wahana yang sengaja dirancangkan untuk menstimulasi berbagai aspek perkembangan pada anak usia dini.

Pembelajaran dengan pendekatan sentra merupakan kegiatan belajar yang berpusat pada anak (student Centered), dimana setiap anak mendapatkan kesempatan untuk belajar sambil melakukan kegiatan di sentra-sentra yang telah ditentukan. Pendekatan sentra dan lingkaran lebih menekankan pada proses aktualisasi anak dalam kegiatan bermain sambil belajar dan pada klimaks keberhasilan dan kebanggaan terhadap kesuksesan. Selaras dengan teori Maslow tentang hierarki kebutuhan manusia, bahwa anak memiliki kebutuhan aktualisasi diri untuk mewujudkan perkembangan. Perkembangan yang sehat terjadi bila manusia mengaktualisasikan diri dan mewujudkan segenap potensinya. Dengan demikian anak dapat merasakan menjadi orang yang berarti dalam kehidupannya. Konsep dari pusat kegiatan belajar atau sentra juga selaras dengan kata bijak yang dinyatakan oleh Silberman sebagai berikut "What I hear, I forget. What I hear and see, I remember a Little. What I hear, see, and ask question about or discuss with someone else, I begin to understand. What I Teach to another, I master" (Melvin, 2006: 23.). Pernyataan tersebut memiliki filosofi yang mendalam tentang pentingnya melibatkan anak secara aktif dalam pembelajaran.

Terdapat beberapa sentra yang dapat diselenggarakan dalam pembelajaran dengan pendekatan BCCT yaitu (1) Sentra Bermain Peran (Play Hause Centre) adalah kegiatan yang berfokus pada kegiatan dramatisasi. (2) Sentra Persiapan (Readiness Centre) adalah pusat kegiatan bermain dalam persiapan membaca, menulis, matematika. (3) Sentra Seni (Art Centre) adalah sentra yang kegiatannya terdiri dari keterampilan tangan seperti melipat, mengunting, merekat, prakarya, melukis, dan pertukangan. (4) Sentra Bahan Alam (Messy Play Centre) adalah tempat anak melakukan kegiatan dengan berbagai alat yang 
tepat sesuai dengan kebutuhan anak yang terdiri dari alat/ bahan kering dan alat/ bahan yang menggunakan air; (5) Sentra Musik (Musik Centre) adalah sentra yang memusatkan kegiatan seni musik dan jasmani. (6) Sentra Balok adalah tempat kegiatan bermain balok dengan pengawasan guru, berbagai bentuk dan ukuran balok. (7) Sentra agama/Imtaq adalah tempat kegiatan beribadah yang disiapkan didalamnya bermacam-macam perlengkapan ibadah seperti gambar-gambar, buku-buku cerita keagamaan dan sebagainya. Kegiatan yang dilaksanakan adalah menanamkan nilai-nilai kehidupan beragama, keimanan dan ketaqwaan kepada Tuhan Yang Maha Esa.

Kegiatan yang dilakasanakan dalam sentra agama adalah menanamkan nilai-nilai kehidupan beragama, keimanan dan ketaqwaan kepada tuhan yang maha esa. Agama merupakan suatu konsep abstrak yang perlu diterjemahkan menjadi aktivitas kongkrit bagi anak. Kegiatan sentra agama, yang perlu disiapkan adalah berbagai maket tempat ibadah, perlengkapan ibadah, gambar-gambar, buku-buku cerita keagamaan, dan sebagainya (Mutiah, 2012: 133-135). Untuk lebih jauh membahas mengenai konsep pembelajaran huruf hijaiyah pada sentra agama Di TK Tunas 1001 dan kualitas pelaksanaan pembelajaran huruf hijaiyah melalui sentra agama Di TK Tunas 1001 maka langkah penulis adalah menentukan metode yang tepat guna.

\section{METODOLOGI}

Rancangan penelitian ini menggunakan pendekatan kualitatif dengan jenis penelitian lapangan (field research). Data yang diperoleh berasal dari terjun langsung ke lapangan. Penelitian lapangan ini penulis lakukan untuk menemukan pemecahan masalah mengenai pembelajaran huruf hijaiyah pada sentra agama. Dengan kata lain, prinsip penelitian lapangan ini penulis lakukan untuk memecahkan masalah-masalah praktis yang ada dalam dunia pendidikan terkait kurangnya generasi yang mampu membaca al-Qur'an, khususnya untuk mengetahui pelaksanaan pembelajaran huruf hijaiyah pada sentra agama. Adapun metode yang dipakai dalam pengumpulan datanya menggunakan metode deskriptif kualitatif, yakni menggambarkan dengan jelas apa yang terjadi di lapangan. (Mahmud, 2011: 81). Penelitian kualitatif adalah suatu penelitian yang menekankan tentang analisisnya di mana pada proses penyimpulannya berbentuk deduktif dan induktif serta pada menganalisis dinamika hubungan antar fenomena yang sedang atau akan diamati, 
dengan menggunakan logika ilmiah. Lokasi penelitian ini di TK Tunas 1001 dengan fokus penelitian pembelajaran huruf hijaiyah pada sentra agama di TK Tunas 1001.

Sumber data dari penelitian ini terdiri dari data primer dan data sekunder. Pertama Sumber data primer yaitu sebagai sumber data pokok yang digunakan dalam penulisan ini yakni 3 orang guru pada penelitian tentang konsep pembelajaran huruf hijaiyah pada TK Tunas 1001, dalam kelas sentra mencakup 1 kelas dengan jumlah 15 orang anak sehingga sampel yang diambil benar-benar representatif dan mewakili semua data yang akan diolah. Kedua Data sekunder yaitu data pendukung yang diproleh dengan cara mengumpulkan dan mencatat dalam ringkasan-ringkasan maupun ide-ide yang dapat dari buku-buku, majalah, artikel serta tulisan yang berhubungan tentang pembelajaran huruf hijaiyah pada sentra agama.

Teknik pengumpulan data digunakan oleh peneliti untuk memperoleh data dan informasi yang dibutuhkan dalam penelitian ini yaitu pertama observasi yang dapat diartikan sebagai suatu pengamatan dan pencatatan secara sistematik dan terstruktur terhadap gejala yang tampak pada sebuah objek penelitian (Margono, 2009: 158). Observasi juga dapat dikatakan sebagai teknik pengumpulan data yang dilakukan dengan cara mengadakan pengamatan secara teliti dan pencatatan secara sistematis (Sutrisno, 2002: 11). Tujuan observasi adalah untuk mendeskripsikan suatu keadaan yang terjadi, aktivitas, dan melihat makna aktivitas tersebut dari pesfektif informan. Pengumpulan data juga dilakukan dengan wawancara (interview). Teknik pengumpulan data dengan observasi, wawancara, dokumentasi (Arikunto, 2002: 136). Wawancara ini dilakukan peneliti kepada guru Taman Kanak-Kanak Tunas 1001. Wawancara dilakukan dengan mengajukan beberapa pertayaan yang berhubungan dengan pembelajaran huruf hijaiyah pada sentra agama di Taman Kanak-Kanak Tunas 1001. Untuk melengkapi data-data yang diperoleh melalui wawancara dan observasi juga diperlukan data-data yang tertulis atau bukti fisik, tercatat yang dipakai sebagai bukti atau keterangan. Wawancara yang dilakukan dengan kepala sekolah dan pendidik yang dianggap mampu mengasilkan data yang valid dan lengkap mengenai pembelajaran huruf hijaiyah pada sentra agama. Penggunaan metode dokumentasi merupakan sarana pelengkap sehingga data yang diperoleh lebih banyak dan lengkap. Analisis data dilakukan dengan menyusun secara sistematis, data 
yang diperoleh melalui observasi atau pengamatan, interview atau wawancara, dokumentasi dan bahan-bahan lain. Sehingga mudah dipahami dilakukan dengan mengorganisasikan data, menyusun, memilah dan membuat kesimpulan data, artinya penelitian dalam mengumpulkan data juga menganalisi data yang diperoleh dari lapangan.

\section{HASIL DAN PEMBAHASAN}

\section{Konsep Pembelajaran Huruf Hijaiyah Pada Sentra Agama Di TK Tunas 1001}

Pembelajaran huruf hijaiyah melalui sentra agama Di TK Tunas 1001 dilakukan untuk menanamkan nilai-nilai keagamaan, keimanan dan ketaqwaan terhadap Allah SWT. Sentra agama yang berisi berbagai kegiatan untuk menanamkan nilai-nilai agama dalam rangka mengembangkan sifat religius anak. Adapun konsep pembelajaran yang diterapkan yaitu belajar sambil bermain secara efektif membuat antusiasme anak dalam mengikuti proses pembelajaran disentra ibadah. Antusiasme tersebut terlihat ketika anak serius saat melakukan berbagai macam kegiatan yang dilakukan pada sentra tersebut. Pelaksanaan pendidikan yang diberikan bukan hanya menjadikan manusia yang pintar dan terampil, akan tetapi setiap pembelajaran harus memiliki konsep pembelajaran yang jelas, salah satu konsep pembelajaran huruf hijaiyah pada sentra agama di TK Tunas 1001 diterapkan sambil bermain dan bermain sambil belajar. Konsep pembelajaran huruf hijaiyah pada sentra agama yaitu belajar sambil bermain dan praktek yang mana pembelajaran tersebut diterapkan dengan menggunakan lagu-lagu, tebak-tebakkan serta bermain puzzle karena dalam mengenalkan huruf hijaiyah pada anak tidak harus selalu diartikan sebagai kegiatan menyajikan materi pelajaran, meskipun penyajian materi pelajaran memang merupakan bagian dari kegiatan pembelajaran. Membuat konsep yang menarik bagi anak yakni dengan cara yang menyenangkan sehingga anak dapat lebih mudah dan cepat dalam menguasai pembelajaran yang diberikan (Wasliyah, 2017:09:20).

Upaya yang dilakukan dalam mengoptimalkan pembelajaran huruf hijaiyah adalah dengan menerapkan metode pembiasaan yaitu pembelajaran yang diterapkan dengan menggunakan poster atau kartu huruf, pembiasaan itu dilakukan dengan selalu mengucapkan huruf hijaiyah dengan benar, jadi setiap pagi dikhususkan kepada anak wajib membacakan huruf hijaiyah, agar dengan pembiasaan itu anak terlatih dan hapal 
dengan sendirinya. Jadi mempelajarinya tidak harus didorong, tetapi latih dengan selalu mengucapkan huruf hijaiyah setiap pagi dan mengenalkan kartu huruf hijaiyah, serta berbagai macam nyanyian. Yang sangat penting dengan memahami apa yang diinginkan oleh anak, memahami setiap gerak geriknya dengan begitu dapat mencari solusi agar anak mau belajar dan menuruti apa yang dikatakan oleh gurunya (Hudnah, 2017: 09:40). Pembelajaran huruf hijaiyah dimaknai sebagai pembelajaran yang berkaitan dengan bagian ayat-ayat al-Qur'an sehingga dapat memberikan pengetahuan bahwa kelak anak mampu membaca dengan baik dan benar.

Pembelajaran huruf hijaiyah pada sentra agama kegiatan yang dilakukan adalah melalui sentra. Salah satu sentra yang digunakan untuk membelajarkan huruf hijaiyah adalah pada sentra agama. Terkait perbedaan antara pembelajaran melalui sentra agama dan tidak melalui sentra agama terletak pada lebih kuatnya nilai-nilai yang ditransformasikan dan pembelajaran yang dilakukan lebih fokus serta lebih mudah menguasai pembelajaran. Sedangkan pembelajaran yang tidak memakai sentra agama tidak sepenuhnya dipelajari melainkan hanya garis besarnya saja. Selain itu, media yang digunakan juga tidak beragam, sehingga anak tidak fokus dan sulit untuk memahami serta menguasai pembelajaran yang ditetapkan. Pembelajaran yang telah dibuat menarik dan menyenangkan dapat membuat anak antusias dalam mengikuti pembelajaran. Antusias anak dalam belajar pada pembelajaran huruf hijaiayah melalui sentra agama tidak akan berhasil tanpa adanya strategi pembelajaran yang bagus (Wasliyah, 2017: 09: 20).

Dapat dipahami bahwa strategi pembelajaran huruf hijaiyah pada sentra agama yang telah diterapkan adalah dengan cara membiasakan anak untuk selalu mengucapkan huruf hijaiyah berulang-ulang kemudian anak juga dapat bermain kartu huruf atau bermain bebas dengan kartu tersebut strategi selanjutnya anak dapat melatih kemampuan menulis dan pengucapannya dengan cara menulis huruf hijaiyah pada buku yang berbentuk kotakkotak, maka pembelajaranpun dapat berlangsung dengan baik. Pembelajaran huruf hijaiyah pada sentra agama terletak pada kegiatan bermain puzzle huruf hijaiyah dan kartu huruf, kegiatan tanya jawab serta pemberian tugas untuk menebali huruf hijaiyah.

Konsep pembelajaran huruf hijaiyah pada sentra agama yang bertujuan untuk meningkatkan kemampuan mengenal huruf hijaiyah anak dan mengembangkan aspek- 
aspek perkembangan anak, karena dalam sentra agama ini banyak terdapat benda-benda yang mampu membuat anak lebih mengenal huruf hijaiyah dengan baik. Untuk memperlancar proses pencapaian tujuan pembelajaran disentra agama ini perlu guru yang memiliki wawasan tentang huruf hijaiyah dan mengerti tentang konsep pembelajaran yang baik sangatlah dibutuhkan. Karena guru adalah orang yang dipercaya untuk membentuk karakter anak di pendidikan formal. Dalam masalah pemilihan konsep pembelajaran, sebaiknya memperhatikan perkembangan anak, jika kita tidak memperhatikan serta memahami perkembangan anak, guru sulit menerapkan pembelajaran, maka dari itu pemahaman guru terhadap seluruh asfek-asfek pendidikan sangat penting dan salah satunya adalah pemahaman tentang konsep pemeblajaran itu sendiri.

\section{Pelaksanaan Pembelajaran Huruf Hijaiyah Melalui Sentra Agama Di TK}

\section{Tunas 1001}

Pembelajaran menjadi tidak berarti jika tidak menghasilkan kualitas atau proses pembelajaran yang baik kepada anak. Pembelajaran hanya akan berhasil jika kualitas pembelajaran menarik dan mengasilkan anak yang cerdas dan berakhlaq mulia. Program pembelajaran huruf hijaiyah pada anak usia dini di Taman Kanak-Kanak Tunas 1001 Takengon meliputi yaitu: pertama menanamkan dasar-dasar nilai agama kepada anak, kedua dasar untuk bisa membaca Al-Qur'an, ketiga Agar memajukan generasi muda yang berakhlaq mulia dan berbudi pekerti. Guru sebagai pendidik sebaiknya mempertimbangkan aspek psikologis anak. Pembelajaran huruf hijaiyah pada sentra agama dilakukan dengan kegiatan pembiasaan serta menggunakan berbagai macam metode dengan tujuan agar anak terbiasa melakukan kegiatan yang berkaitan dengan keagamaan.

Terkait metode pembelajaran huruf hijaiyah yang digunakan pada sentra agama di Taman Kanak-Kanak Tunas 1001 Takengon yaitu metode pembiasaan kegiatan yang dilakukan mengucapkan huruf hijaiyah secara berulang-ulang setiap hari dan anak menunjukkan huruf hijaiyah dengan benar. Selain metode pembiasaan juga menggunakan metode bernyanyi. Menurut Wasliyah bahwa metode bercakap-cakap, metode demonstrasi, metode pemberian tugas dan metode bermain, bernyanyi dapat memberikan berbagai wawasan dan imajinasi anak (Wasliyah, 2017: 09: 20). Pembelajaran huruf hijaiyah pada sentra agama di Taman Kanak-Kanak Tunas 1001 Takengon dapat dilakukan melalui 
beberapa langkah, yaitu: a). Kondisi suasana kelas diatur secara menyenangkan, menarik dan penuh dengan nuansa keislaman sehingga mendukung semangat belajar anak. Hal ini tampak pada desain dinding yang penuh dengan hiasan-hiasan kalimat thayibah, hurufhuruf hijaiyah, nama-nama malaikat, nabi-nabi, gambar orang shalat, doa shalat, namanama allah (Asmaul Husna), warna-warna terang yang pada intinya sangat menarik perhatian anak. Dengan begitu suasana kelas tidak lagi membosankan, tetapi justru menciptakan suasana edukatif, menyenangkan dan penuh keceriaan. b). Pembelajaran menekankan pada penanaman nilai-nilai keagamaan dengan memberikan materi-materi pendidikan agama seperti rukun iman, rukun islam, hafalan ayat-ayat pendek, hadist pilihan, do'a-do'a dan lain-lain yang tujuannya menanamkan memori keimanan agar nilainilai tersebut dapat melekat pada jiwa anak, sehingga anak terbiasa untuk melakukannya dalam kehidupan sehari-hari, c) Penyajian materi dikemas dalam suasana bermain sambil belajar, d). Ketika proses pembelajaran dilaksanakan kelas dibiarkan tanpa bangku. Pada proses pembelajaran guru dan anak semuanya duduk melingkar dilantai dengan menggunakan alas sehingga anak bisa leluasa bergerak bebas pada waktu proses pembelajaran, e). Pembelajaran dilaksanakan secara berkelompok dan dengan duduk melingkar, masing-masing kelompok terdapat 4-5 anak dengan satu guru dan membahas tema yang sama, f). Pada pelaksanaan pembelajaran, guru hanya bertindak sebagai fasilitator dan motivator dengan mengkontruksi pemikiran anak, g). Pada proses pembelajaran guru aktif dalam menanamkan keimanan pada anak dengan selalu mengucapkan kalimat Thayibah agar anak terbiasa dan tertanam dihatinya akan Allah yang maha pencipta segalanya, h). Dalam proses pembelajaran menggunakan metode yang bervariasi agar anak tidak mudah bosan, seperti metode pembiasaan tanya jawab, bernyanyi yang digunakan ketika guru sentra menerangkan tentang tema keimanan apa yang dipelajari sehingga anak dapat memahami tema dan materi yang akan dipelajari. i). Melakukan evaluasi, pencatatan, diskusi tentang pembelajaran hari ini dan esok hari dengan guru sentra.

Sentra agama terdapat beberapa keunggulan salah satunya dapat meningkatkan kecerdasan spiritual anak, sehingga anak akan cepat bisa membaca dan menghapal hurufhuruf hijaiyah, surat-surat pendek serta do'a-do'a sehari-hari, anak juga mampu 
mempraktekkan kegiatan ibadah, seperti sholat lima waktu, sholat berjamaah, praktek wudhu, puasa dan haji (Hudnah, 2017: 09:25 ). Pendidikan islam memfokuskan perhatian pada pembentukan kepribadian secara islami. Pembelajaran huruf hijaiyah sangat berperan penting dalam dengan tujuan: mengenalkan Allah kepada anak sebagai pencipta alam semesta, menanamkan kecintaan anak kepada Allah SWT melalui pembiasaan, senang melakukan segala perintah dan meninggalkan segala larangannya sesuai dengan kemampuan anak, membentuk perilaku akhlak anak sebagai sumber daya manusia yang berkualitas, mengembangkan akhlaqul kharimah, mengembangkan aspek rukun iman dan rukun Islam serta mengembangkan aspek-aspek perkembangan anak seperti perkembangan bahasa, motorik, kognitif, sosial. Pembelajaran huruf hijaiyah pada sentra agama dapat mengembangkan bahasa anak terlihat dari pengucapan anak terhadap huruf-huruf hijaiyah, dapat mengembangkan motorik anak terlihat pada kegiatan bermain puzzle serta kartu huruf, mengembangkan kognitif anak sebagaimana proses anak berfikir untuk melakukan aktifitas.

\section{SIMPULAN}

Konsep pembelajaran huruf hijaiyah dimaknai sebagai pembelajaran yang berkaitan dengan bagian ayat-ayat al-Qur'an sehingga dapat memberikan pengetahuan bahwa kelak anak mampu membaca dengan baik dan benar. Proses pembelajaran huruf hijaiyah dengan sentra agama dilakukan dengan perencanaan hingga penilaian sehingga aspek perkembangan bahasa, motorik, kognitif, sosial anak dapat tercapai. Dengan membelajaran huruf hijaiyah kepada anak sejak dini dapat meminimalisir generasi yang kurang mampu membaca Al-Qur'an sehingga dasar agama dapat terinternalisasikan dalam keseharian

\section{DAFTAR PUSTAKA}

Ahmad, Susanto. (2011). Perkembangan Anak Usia Dini. Jakarta: Kencana Prenada Media Group.

Arsyad, Azhar. (1999). Bahasa Arab Dan Metode Pengajaranya. Yogyakarta: Pustaka Pelajar

Carol, Seefeldt. Wasik Barbara A. (2006). Pendidikan Anak Usia Dini. Alih Bahasa: Pius Nasar. Jakarta: Indeks.

Depdiknas. (2006). Pedoman Penerapan Pendekatan "Beyond Centers And Circle Time $(B C C T)$ " (Pendekatan Sentra Dan Lingkaran Dalam Pendidikan Anak Usia Dini. 
Diana, Mutiah. (2012). Psikologi Bermain Anak Usia Dini. Cetakan II. Jakarta: Prenada Media Group

Hamalik, Oemar. (2013). Kurikulum Dan Pembelajaran. Cet 13. Jakarta: Bumi Aksara.

Harun, Rasyid. Dkk. (2009). Asessmen Perkembangan Anak Usia Dini. Yogyakarta: Multi Pressindo.

Imroatun. (2017). Pembelajaran Huruf Hijaiyah bagi Anak Usia Dini. Proceedings of The 2nd Annual Conference on Islamic Early Childhood Education (C) 2017 Study Program of Islamic Education for Early Childhood, Faculty of Tarbiyah and Teaching Science (pp.175-188). State Islamic University Sunan Kalijaga Yogyakarta. Volume 2. August.

Mahmud. (2011). Metode Penelitian Pendidikan. Bandung: Pustaka Setia.

Margono. (2009). Metode Penelitian (Komponen MKDK). Cet-VI. Jakarta: Rineka Cipta.

Mursid. (2015). Belajar Dan Pembelajaran Paud. Cet II. Bandung: Remaja Rosdakarya

Silberman, Melvin L. (2006). Active Lerning, 101 Cara Belajar Siswa Aktif. Terj, Raisul Muttaqien. Bandung: Nusamedia.

Slamet, Suyanto. (2005). Kosep Dasar Pendidikan Anak Usia Dini. Yogyakarta: Universitas Negeri Yogyakarta.

Suharsimi, Arikunto. (2002). Prosedur Penelitian Suatu Pendekatan Praktek. Jakarta: Rineka Cipta.

Sutrisno, Hadi. (2002). Metodologi Reserach II. Yogyakarta: Andi Offset.

Suyadi. Maulidya Ulfa. (2013). Konsep Dasar Paud. Cet- II. Bandung: Remaja Rosdakarya.

Yunus, Abidin. (2014). Desain Sistem Pembelajaran Dalam Konteks Kurikulum. Cet KeII. Bandung: Refika Aditama. 